J-ABDIPAMAS (Jurnal Pengabdian Kepada Masyarakat)

Vol. $4 \bullet$ No. $2 \bullet 2020$

ISSN : 2581-1320 (Print) ISSN : 2581-2572 (Online)

Homepage: http://ejurnal.ikippgribojonegoro.ac.id/index.php/J-ABDIPAMAS

\title{
PENGEMBANGAN INOVASI PRODUK ROTI PADA HOME INDUSTRY ANDIL JAYA BAKERY BUGO JEPARA
}

\author{
Ali Sofwan ${ }^{1}$, Octavianti Paramitha ${ }^{2}$, Harminto Mulyo ${ }^{3}$, Hayu Dian Yulistianti ${ }^{4}$, Santi \\ Andriyani ${ }^{5}$, Nusrotus Sa'idah ${ }^{6}$ \\ ${ }^{1}$ UNISNU Jepara. Email: alisofwan1047@unisnu.ac.id \\ 2UNNES Semarang. Email: octavianti.paramita@mail.unnes.ac.id \\ 3UNISNU Jepara. Email: minto@unisnu.ac.id \\ 4UNISNU Jepara. Email: hayu@unisnu.ac.id \\ 5UNISNU Jepara. Email: santi@unisnu.ac.id \\ 6UNISNU Jepara. Email: nusrotus@unisnu.ac.id
}

\begin{abstract}
Andil Jaya Bakery is one of the home bakery industries in the village of Bugo Jepara. Based on the observations result made by the team, the partner's problems were the lack of productivity and product innovation so that the development of partners' businesses did not develop maximally. The purpose of this service program is to provide training and assistance on product innovation. The methods used are; 1) on the product aspect, the team give fasility to partners by give them a planetary mixer; and 2) in the production aspect, the team conducts activities and product innovation training. The result of this activity is the creation of bread product innovations in the form of roti sisir and roti kasur with various flavors, namely chocolate, pineapple, strawberry and cheese.
\end{abstract}

Keywords: product innovation, home bakery industry, regional superior products

\begin{abstract}
ABSTRAK
Andil Jaya Bakery merupakan salah satu home industri roti yang ada di desa Bugo Jepara. Berdasarkan hasil observasi yang telah dilakukan oleh tim, permasalahan yang dimiliki oleh mitra adalah kurangnya produktifitas dan inovasi produk sehingga perkembangan usaha mitra tidak berkembang secara maksimal. Tujuan dari pengabdian ini adalah untuk memberikan pelatihan dan pendampingan mengenai inovasi produk. Adapun metode yang digunakan adalah; 1) pada aspek produk, tim memberi vasilitas kepada mitra dengan memberikan alat mixer planetary; dan 2) pada aspek produksi, tim mengadakan kegiatan dan pelatihan inovasi produk. Hasil dari kegiatan ini adalah terciptanya inovasi produk roti berupa roti sisir dan roti kasur dengan berbagai varian rasa, yaitu coklat, nanas, strawberi dan keju.
\end{abstract}

Kata Kunci: inovasi produk, home indutri roti, produk unggulan daerah

\section{PENDAHULUAN}

Bisnis roti merupakan salah satu bisnis yang menjanjikan bagi yang menggelutinya, kue jenis ini merupakan camilan yang enak dan mengenyangkan. Selain itu faktor yang mempengaruhinya yaitu dilihat dari peminatnya dari berbagai kalangan (Augustinah,dkk 2017). Desa Bugo kecamatan welahan merupakan sentra produksi roti yang cukup 
terkenal di kota Jepara. Rata-rata penduduk di desa Bugo memiliki home industri sendirisendiri. Salah satu home industri yang ada di desa Bugo adalah "Andil Jaya Bakery" yang akan menjadi mitra pengabdian masyarakat dalam Program Pengembangan Produk Unggulan Daerah (PPUD). Home industri ini berdiri kurang lebih 30 tahun dengan nama pemilik H. Sunoto, dimana pada saat mendirikan usahanya pertama yaitu kue tambang, ketawa dan kue pisang. Seiring dengan berkembangnya usaha produknya bertambah yaitu kue pia basah kacang ijo dan kelapa, roti coklat wijen, pisang coklat panggang, pisang molen serta donat.
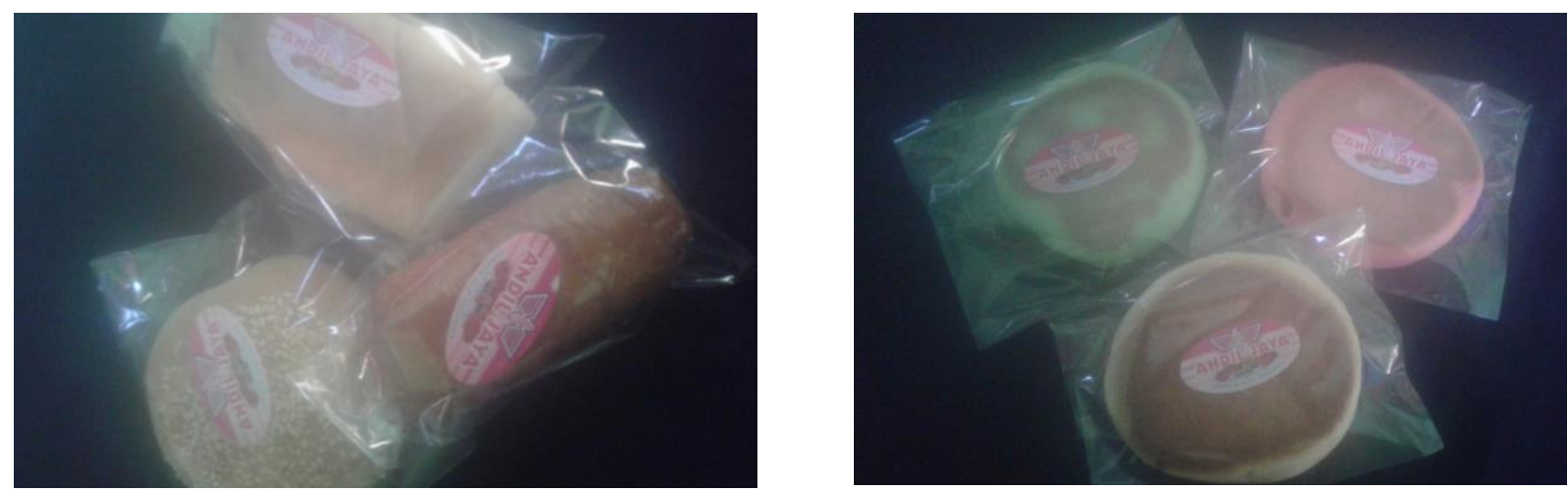

Gambar 1. Produk aneka varian roti Andil Jaya Bakery

Usaha Boga ini mempunyai karyawan sebanyak 6 orang dengan ketentuan 2 orang bagian membuat adonan dengan cara tradisional belum memilki tempat adonan yang higienis, menghaluskan adonan dengan mesin yang disebut dengan "Roll" serta memotong ukuran adonan sesuai dengan bentuk roti. Untuk yang lainnya bagian menata adonan dan membuat adonan jadi bentuk bulat, lingkar seperti donat ataupun pisang molen serta memasukkan roti dalam kemasan plastik.

Omset setiap harinya sebesar kurang lebih 600 buah yang dipasarkan Pecangaan, Karangaji, Mayong, Welahan, Bangsri, Demak, Gajah. Penjualan melalui sales atau pedagang langsung yang jual di pasar. Harga per buar rotinya yaitu RP 700,- rupiah dengan eceran Rp 1000,- akhir konsumen. Pembuatan Roti tersebut diantaranya menggunakan peralatan diantaranya: meja pengaduk bahan, mesin penghalus adonan, meja untuk membentuk adonan, penggorengan oven (pemanggang Roti), loyang, timbangan elektrik ,

Berikut Proses produksi dalam pembuatan roti : pertama, semua bahan dicampur dalam meja adukan kemudian diamkan kurang lebih sekitar 5 menit, setelah itu adonan dihaluskan dengan mesin penghalus. Kedua, setelah adonan sudah halus, adonan di oven kurang lebih 20 menit, setelah selesai adonan dipotong sesuai dengan ukurang timbangan elektrik. Terakhir , roti siap dikemas.

Berdasarkan hasil wawancara dengan mitra, Proses produksi selama ini masih belum menghasilkan adonan yang baik. Karena keterbatasan alat yang mumpuni untuk menghasilkan adonan roti dengan kualitas yang lebih baik. Proses pengadukan dan pengulenan yang masih manual akan berdampak pada hasil adonan dengan kualitas 
rendah, cita rasa dan ketahanan adonan selama penyimpanan kurang higienies dan tidak menarik (Muntasir \& Prilmayanti, 2017).

Lima tahun terakhir ini produksi kue basah ini mengalami penurunan. Karena banyak pesaing dengan inovasi produk yang lebih bervariasi. Untuk pemilik sendiri jarang mengikuti pelatihan tentang inovasi produk untuk pengembangan inovasi di tempat usahanya. Usaha roti ini belum dapat di prediksi pemasaran dalam tiap bulan dikarenakan ada beberapa bulan omset naik kadang juga turun. Biasanya pada waktu musim bulan Haji, Maulud dan Rajab omset dapat meningkat karena adanya kebutuhan konsumen.

Berdasarkan hasil wawancara dan observasi kepada mitra, ada beberapa persoalan yang melingkupi mitra tersebut, yaitu: 1) kurang inovasi mitra dalam pengembangan produk roti; 2) kurang terampilnya mitra dalam pembuatan roti ; 3) berkurangnya pelanggan roti karena produknya tidak bervariasi; 4 omset dan produktifitas semakin turun.

Berdasarkan analisis situasi dan permasalahan di atas, maka tujuan dari program pengabdian ini adalah:

Tabel 1. Tujuan Program Pengabdian

\begin{tabular}{lll}
\hline No & Aspek & Tujuan \\
\hline 1 & Produksi & Untuk meningkatkan kualitas produksi melalui \\
& & pengadaan alat mesin adonan mixer/planetary \\
2 & Produk & a. Untuk meningkatkan inovasi produk sehingga \\
& produk mitra bisa bervariasi sesuai dengan \\
& & kebutuhan pasar. \\
& & b. Untuk melegalkan produk dengan sertifiikat halal \\
& & \\
&
\end{tabular}

Pentingnya inovasi produk dalam meningkatkan produktivitas home industri sesuai dengan beberapa hasil penelitian, diantaranya :

Tabel 2. Hasil Penelitian yang Berkaitan dengan Program

\begin{tabular}{|c|c|c|}
\hline No & Judul Dan Penulis & Hasil \\
\hline 1 & $\begin{array}{l}\text { Analisis Faktor-Faktor Pengaruh } \\
\text { Inovasi Produk Yang Berdampak } \\
\text { Pada Keunggulan Bersaing UKM } \\
\text { Makanan Dan Minuman Di } \\
\text { Wilayah Harjamukti Kota Cirebon } \\
\text { (Aang Curatman, Dkk: 2016) . }\end{array}$ & $\begin{array}{l}\text { Hasil penelitian menunjukan bahwa } \\
\text { orientasi strategik(x1) dan orientasi } \\
\text { pasar(x2) berpengaruh secara } \\
\text { signifikan terhadap inovasi produk } \\
\text { (y1) dengan taraf uji } \alpha=5 \% \quad(p- \\
\text { value }=0,022<\alpha) \text {. Inovasi produk } \\
\text { memiliki pengaruh positif terhadap } \\
\text { keunggulan bersaing sebesar } 13.1 \% \text {. } \\
\text { Hal ini berarti bahwa apabila } \\
\text { perusahaan ingin mempunyai } \\
\text { keunggulan bersaing, maka perusahaan } \\
\text { dapat menciptakannya melalui }\end{array}$ \\
\hline
\end{tabular}




\begin{tabular}{|c|c|c|}
\hline & & $\begin{array}{l}\text { kegiatan-kegiatan inovasi terhadap } \\
\text { produk yang dihasilkannya. }\end{array}$ \\
\hline 2 & $\begin{array}{l}\text { Inovasi Produk Pada Roti Ceria Di } \\
\text { Jember } \\
\text { (Yulia Rafelia Saputri,Dkk : 2015) }\end{array}$ & $\begin{array}{l}\text { Hasil dari penelitian ini menunjukkan } \\
\text { bahwa roti ceria mengaplikasikan } 6 \\
\text { tipe dalam inovasi produk yaitu: 1) } \\
\text { produk berbasis modulasi; 2) inovasi } \\
\text { produk berbasis ukuran; 3) inovasi } \\
\text { produk berbasis pengemasan; 4) } \\
\text { inovasi produk berbasis desain; 5) } \\
\text { Inovasi berbasis bahan komplementer; } \\
\text { dan 6) inovasi berbasis pengurangan } \\
\text { upaya. }\end{array}$ \\
\hline 3 & $\begin{array}{l}\text { Pengelolaan Dan Pengembangan } \\
\text { Usaha Pengolahan Roti Pada Pt. } \\
\text { Xyz Di Depok (Jonathan } \\
\text { Paramasatya Setiaji dan Dhyah } \\
\text { Harjanti: 2013) }\end{array}$ & $\begin{array}{l}\text { Hasil dalam penelitian ini } \\
\text { menunjukkan bahwa pt. Xyz memiliki } \\
\text { pengelolaan usaha yang baik. Serta } \\
\text { memiliki kekuatan pada kualitas } \\
\text { produknya. Kelemahannya terletak } \\
\text { pada manajemen tenaga kerjanya. } \\
\text { Perusahaan dapat menggunakan } \\
\text { strategi kepemimpinan biaya sebagai } \\
\text { strategi perusahaan dan melakukan } \\
\text { pengembangan bisnis dengan menekan } \\
\text { biaya produksi, dan penetapan insentif } \\
\text { untuk meningkatkan kinerja }\end{array}$ \\
\hline 4 & \begin{tabular}{l} 
Pengaruh Inovasi Produk, Kualitas \\
Produk Dan Harga Terhadap \\
Keputusan Pembelian Di Toko Roti \\
Dan Kue Ferissa \\
Yogyakarta (Yulianita \\
\multicolumn{2}{l}{ Susanto: 2017$)$}
\end{tabular} & $\begin{array}{l}\text { Hasil penelitian menyimpulkan bahwa } \\
\text { Secara simultan variabel inovasi } \\
\text { produk, kualitas produk dan harga } \\
\text { memiliki pengaruh yang signifikan } \\
\text { terhadap keputusan pembelian. Hal ini } \\
\text { dibuktikan dengan nilai f yaitu sebesar } \\
63.712 \text { dengan tingkat signifikansi } \\
0,000<0,05 \text {. Sedangkan nilai } r=0,680 \text {, } \\
\text { artinya inovasi produk, kualitas produk } \\
\text { dan harga mempunyai hubungan yang } \\
\text { kuat terhadap keputusan pembelian } \\
\text { dan adjusted r square ( } 2 \text { ) sebesar } \\
0,669 \text { artinya sebesar } 66,9 \% \\
\text { menyumbangkan perubahan variabel } \\
\text { inovasi produk, kualitas produk, dan } \\
\text { harga terhadap keputusan pembelian } \\
\text { dan sisanya 33,1\% dipengaruhi oleh } \\
\text { variabel lain yang tidak ada di } \\
\text { penelitian ini. }\end{array}$ \\
\hline
\end{tabular}


Metode pada kegiatan pengabdian ini terfokus pada aspek produksi dan aspek produk. Berikut deskripsinya:

Tabel 3. Hasil Penelitian yang Berkaitan dengan Program

\begin{tabular}{|c|c|c|}
\hline Aspek & Indikator Kegiatan & Metode pelaksanaan \\
\hline Aspek Produksi & $\begin{array}{l}\text { - Kontrol mutu pada } \\
\text { proses produksi } \\
\text { - Efisiensi waktu dalam } \\
\text { produksi }\end{array}$ & $\begin{array}{l}\text { a. Pengadaan mesin mixer } \\
\text { planetary Fomac Uk. } 30 \mathrm{~L} \\
\text { b. Tutorial penggunaan dan } \\
\text { perawatan mesin oleh tim } \\
\text { pengabdian dengan tepat. }\end{array}$ \\
\hline Aspek Produk & 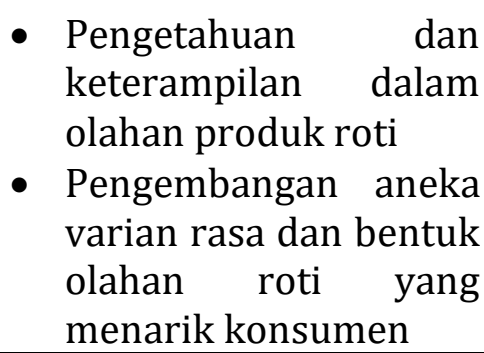 & $\begin{array}{l}\text { a. sosialisasi dan pelatihan } \\
\text { terhadap karyawan dan } \\
\text { pemilik usaha boga tentang } \\
\text { inovasi produk roti dari segi } \\
\text { bentuk dan rasa. } \\
\text { Kegiatan ini dilakukan pada } \\
\text { tanggal 16-17 Juli } 2020 .\end{array}$ \\
\hline
\end{tabular}

\section{HASIL DAN PEMBAHASAN}

Kegiatan pengabdian masyarakat pada home industri roti Andil Jaya diawali dengan koordinasi tim pengadian bersama mitra untuk menentukan kegiatan pelatihan dan pendampingan dalam olahan produk roti meliputi pengembangan varian rasa dan bentuk. Adapun metode pelaksanaan terdiri dari beberapa aspek yaitu:

Pertama adalah aspek produksi. Kegiatan yang dilakukan pada aspek produksi yaitu : Tim melakukan survey dan membeli mesin adonan mixer planetary kapasitas 30L, menggunakan listrik, lebih efisien dan higienis dalam proses produksi. Tim juga memberikan tutorial penggunaan dan perawatan mesin adonan mixer sesuai standar.

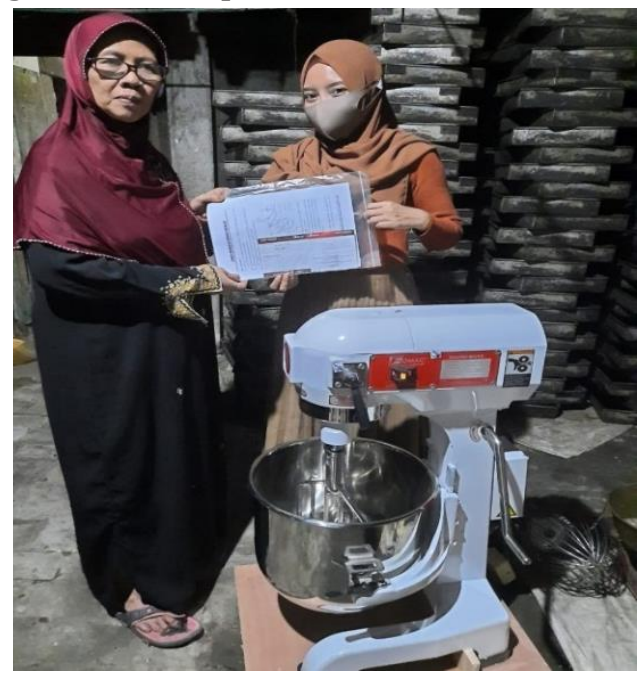

Gambar 2. Mixer Planetary $30 \mathrm{~L}$

Kedua adalah aspek Produk. Pada kegiatan ini dilakukan pada tanggal 16-17 Juli 2020 tim pengabdian bersama tutor teknis pengolahan roti di home industry roti "Andil Jaya Bakery". Adapun tahapan kegiatan yaitu pertama, memberikan pengetahuan cara produksi yang baik, memberi pengetahuan tentang perencanaan produksi, pembelian 
bahan, pengolahan produk, kegiatan menjaga hasil produksi, perawatan tempat dan alat produksi. Home industry ini stock bahan produksi tidak banyak, apabila kebutuhan bahan habis kadangkala menggantinya dengan produk lain yang mempunyai fungsi yang sama tetapi ternyata kualitas hasil berbeda.

Untuk pelaksanaan pelatihan, dilakukan oleh tim pengabdi, tutor teknis dalam pengolahan roti dan 6 tenaga kerja dengan tahapan, yaitu tim dengan mitra menyiapkan bahan-bahan yang akan digunaan untuk membuat roti manis, bahannya adalah : a) 1000 gram tepung terigu protein tinggi; b) 250 gram gula pasir; c)50 gram susu bubuk; d)2,5 sdm ragi instant; e) 1 sdt bread improver; f) 1 butir telur utuh; g)3 butir kuning telur; h)500 ml air es; i)175 gram margarin; j)1 sdt garam.

Ketiga adalah pembuatan produk, tahapan pertama adalah para mitra mencampur tepung terigu,gula pasir,ragi instan dan bread improver, kemudian menambahkan telur,menguleni, menuang air es sedikit demi sedikit sambil diuleni hingga kalis. Tahapan kedua, mitra dengan didampingi tim menambahkan margarin kemudian garam ,menguleni kembali hingga adonan elastis. Tim juga memberikan keterampilan cara membulatkan adonan yang telah kalis.

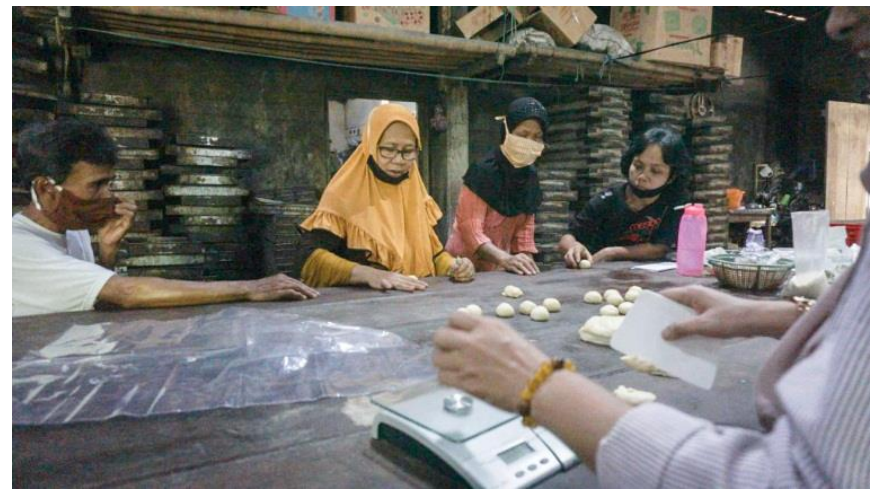

Gambar 3. Mitra sedang membentuk bulatan-bulatan adonan sebelum dibentuk roti manis

Tahapan ketiga adalah membentuk bulatan adonan menjadi roti manis, yaitu roti sisir dan roti kasur. Untuk kemudian di taruh diloyang, untuk di oven.

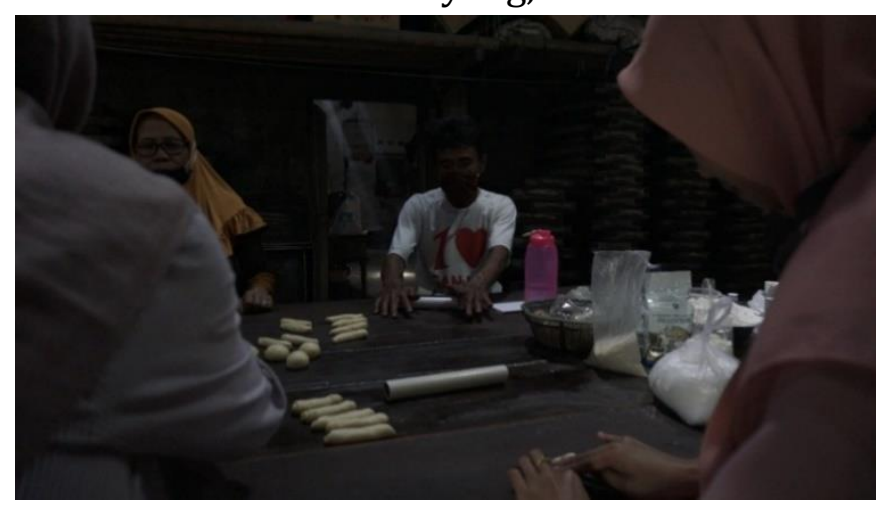

Gambar 4. Proses pembentukan roti manis

Tahapan keempat adalah, proses isian roti. Pada pendampingan ini, isian yang digunakan adalah coklat, nanas, strawberry dan keju. Para mitra antusias dalam proses ini. 


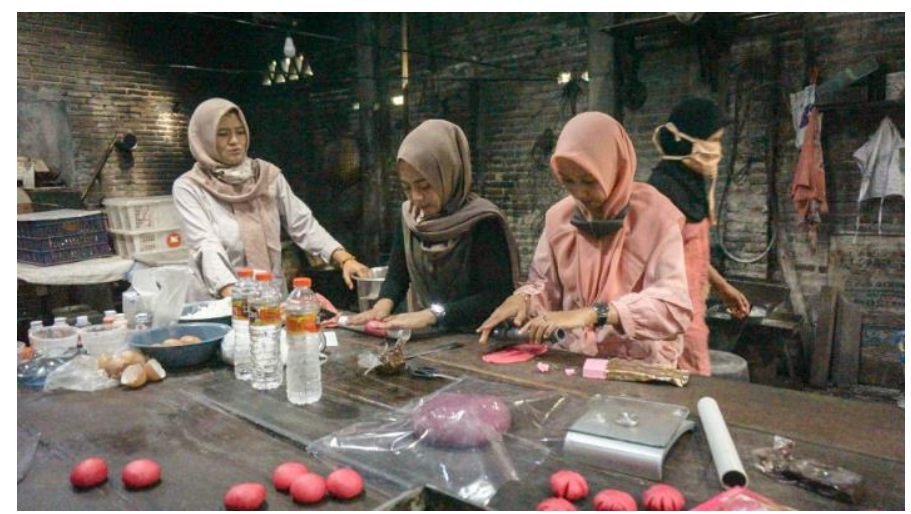

Gambar 5. Proses isian dan inovasi rasa pada produk

Tahapan kelima adalah pengemasan. Setelah roti sudah siap, kemudian dikemas menggunakan plastik sesuai ukuran roti.

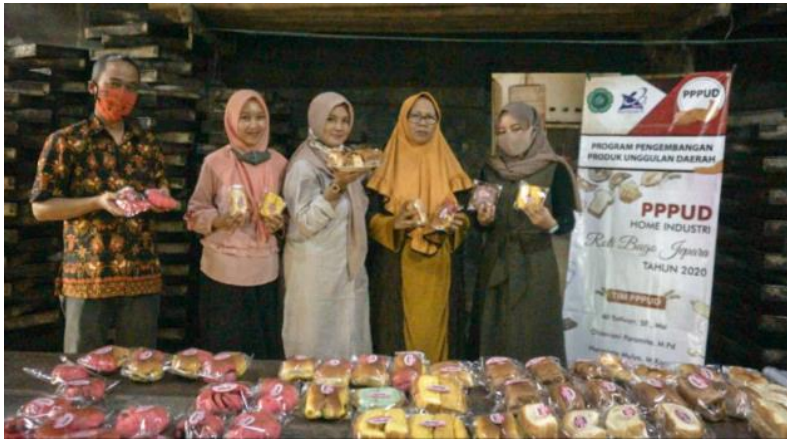

Gambar 6. Proses Pengemasam

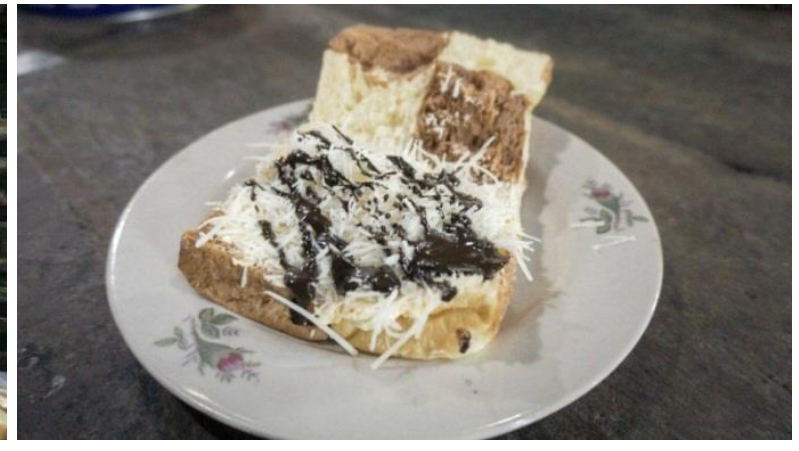

Gambar 7. Hasil pelatihan Tim bersama Mitra

\section{SIMPULAN}

Simpulan dari pengabdian yang telah dilakukan adalah untuk meningkatkan produktifitas dan keterampilan mitra melalui pelatihan dan inovasi produk. Adapun metode yang digunakan adalah; 1) pada aspek produk, tim memfasilitasi mitra berupa alat mixer planetary; dan 2) pada aspek produksi, tim mengadakan kegiatan dan pelatihan inovasi produk. Hasil dari kegiatan ini adalah terciptanya inovasi produk roti berupa roti sisir dan roti kasur dengan berbagai varian rasa, yaitu coklat, nanas, strawberi dan keju.

\section{UCAPAN TERIMA KASIH}

Tim pengabdian mengucapkan terimakasih kepada DRPM Hibah ristekdikti tahun pendanaan 2020 atas dukungan dan fasilitasi pendanaan sehingga program dapat berjalan dengan lancar. Selain itu, kami juga menyampaikan terimakasih kepada UNSNU melalui LPPM UNISNU Jepara atas bimbingan dan arahan sehingga program berjalan sesuai dengan harapan.

\section{DAFTAR RUJUKAN}

Augustinah, dkk. (2017). Manajemen Usaha Dan Pembuatan Kemasan Serta Labeling Home Industri Kue Basah Pada Usaha Kelompok Dasawisma Kri Nanggala Medokan Semampir Surabaya.Surabaya: Universitas Dr. Sutomo 
Curatman, A. (2016). Analisis Faktor-faktor Pengaruh Inovasi Produk yang Berdampak pada Keunggulan Bersaing UKM Makanan dan Minuman di Wilayah Harjamukti Kota Cirebon. LOGIKA Jurnal Ilmiah Lemlit Unswagati Cirebon, 18(3), 61-75.

Muntasir \& Prilmayanti, S. (2017). Aplikasi Teknologi Tepat Guna pada Pembuatan Kue Donat, Kue Roti dan Roti Goreng pada Mitra Usaha Roti Sari dan Dian Jaya Kota Kupang. Jurnal Jati Emas. Vol 1. No.2. Jatim : Forum Dosen Indonesia (FDI)

Saputri, Y. R, et al. (2015). Inovasi Produk pada Roti Ceria di Jember.

Setiaji, J. P. (2013). Pengelolaan dan Pengembangan Usaha Pengolahan Roti pada PT. XYZ di Depok. Agora, 1(1), 663-671.

Susanto, Y. W. (2017). Pengaruh Inovasi Produk, Kualitas Produk dan Harga Terhadap Keputusan Pembelian di Toko Roti dan Kue Ferissa Bantul Yogyakarta. Skripsi. Prodi Manajemen UPY. 